\title{
LETTER
}

\section{Carbonaceous matter in quartz veins and pelitic rocks from the Ryoke metamorphic belt in the Yanai district, SW Japan}

\author{
Tomoe HiROTAKA and Kenichi Hoshino
}

\author{
Department of Earth and Planetary Systems Science, Hiroshima University, Higashi-Hiroshima 739-8526, Japan
}

\begin{abstract}
Carbonaceous matter (CM) with various modes of occurrence has been observed in quartz veins in the biotite zone of the Ryoke metamorphic belt in the Yanai district, Yamaguchi Prefecture, SW Japan. Raman spectroscopic analysis of the CM revealed that high temperature fluids had percolated through fractures, which were now occupied by the quartz veins that had formed during the retrograde stages of metamorphism. These fluids may have also affected the degree of organization of the fine-grained CM particles in the host pelitic rocks and the coarse-grained particles that had precipitated from them at a later stage.
\end{abstract}

Keywords: Ryoke metamorphic rock, Fluid inclusion, Solid inclusion, Carbonaceous matter

\section{INTRODUCTION}

The degree of organization (also called graphitization or crystallinity) of carbonaceous matter (CM) in metamorphic rocks has long been investigated using X-ray diffraction (XRD) analysis (e.g., Landis, 1971; Wada et al., 1994), optical studies (e.g., Okuyama-Kusunose and Itaya, 1987), and Raman spectroscopy (e.g., Pasteris and Wopenka, 1991; Beyssac et al., 2002; Rahl et al., 2005) to estimate the metamorphic conditions of the host rocks.

Although Wang (1989) revealed that the variation of the degree of crystallinity of CM in the Ryoke metamorphic rocks of the Kinki district, Japan, as shown by the XRD data, is consistent with the prograde mineral zones, research into the crystallinity of the well developed Ryoke metamorphic belt in the Yanai district, Yamaguchi Prefecture, SW Japan, has not been reported until now. Since Raman spectroscopy makes it possible to analyze the degree of organization of individual CM grains, we have examined the heterogeneity of the degree of organization of $\mathrm{CM}$ in the quartz veins and their host pelitic rocks of the Ryoke metamorphic belt in the Yanai district.

\section{GEOLOGICAL SETTING AND OCCURRENCE OF THE QUARTZ VEINS}

The Ryoke metamorphic belt in the Yanai district is underlain by Cretaceous granitic rocks and low-pressure

doi:10.2465/jmps.070615

T. Hirotaka, hirotaka821@hiroshima-u.ac.jp

K. Hoshino, hoshino@geol.sci.hiroshima-u.ac.jp Corresponding author
Ryoke metamorphic rocks (Figs. 1 and 2), which are assumed to be the metamorphosed equivalents of the Kuga Group, a Jurassic accretion complex composed mainly of pelitic, psammitic, and siliceous rocks (Okudaira et al., 2001). The metamorphic rocks have been divided into the following seven metamorphic zones in ascending order of metamorphic grade: chlorite, chlorite-biotite, biotite, muscovite-cordierite, $\mathrm{K}$-feldspar-cordierite, sillimanite$\mathrm{K}$-feldspar, and garnet-cordierite zones (Ikeda, 2004).

Quartz veins and pelitic rocks were collected from the Takabatake outcrop in the biotite zone (Fig. 2). According to Yamamoto et al. (2004), the veins occurring in the outcrop are generally orientated parallel to the schistosity and form boudinage due to the ductile flow of the host rock. Yamamoto et al. also concluded that the veins were formed under flow deformation conditions during retrograde metamorphism, probably at temperatures above $300{ }^{\circ} \mathrm{C}$.

\section{SOLID AND FLUID INCLUSIONS}

Electron probe microanalysis has revealed the presence of several solid inclusions in quartz in the veins, including biotite, muscovite, and chlorite. On the other hand, Raman spectroscopy has indicated the occurrence of $\mathrm{CM}$ as solid inclusions and also that rutile is partly substituted by anatase. Such substituted rutile is likely to have been exsolved from biotite before and/or during its alteration to chlorite.

Fluid inclusions in the veins, including the liquid and vapor phases of the $\mathrm{H}_{2} \mathrm{O}-\mathrm{CO}_{2}\left(-\mathrm{CH}_{4}\right)$ system, have been characterized using Raman spectroscopic analysis. Micro- 


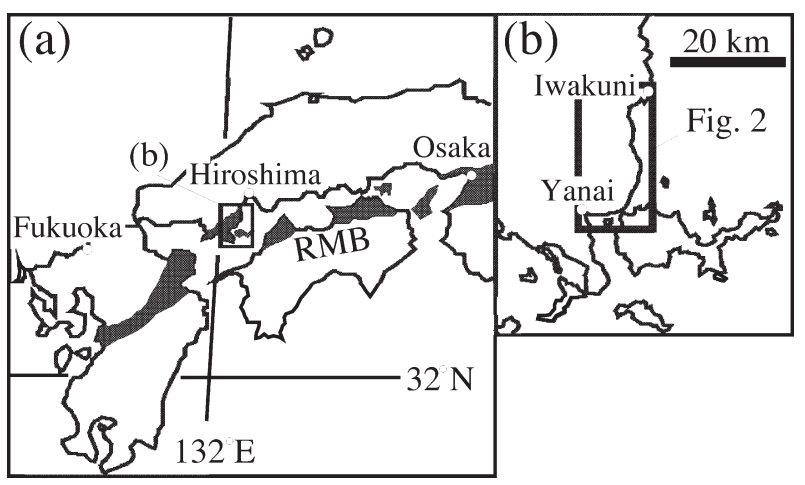

Figure 1. (a) Index map of the Ryoke metamorphic belt (RMB) in SW Japan. (b) Location of the area studied.

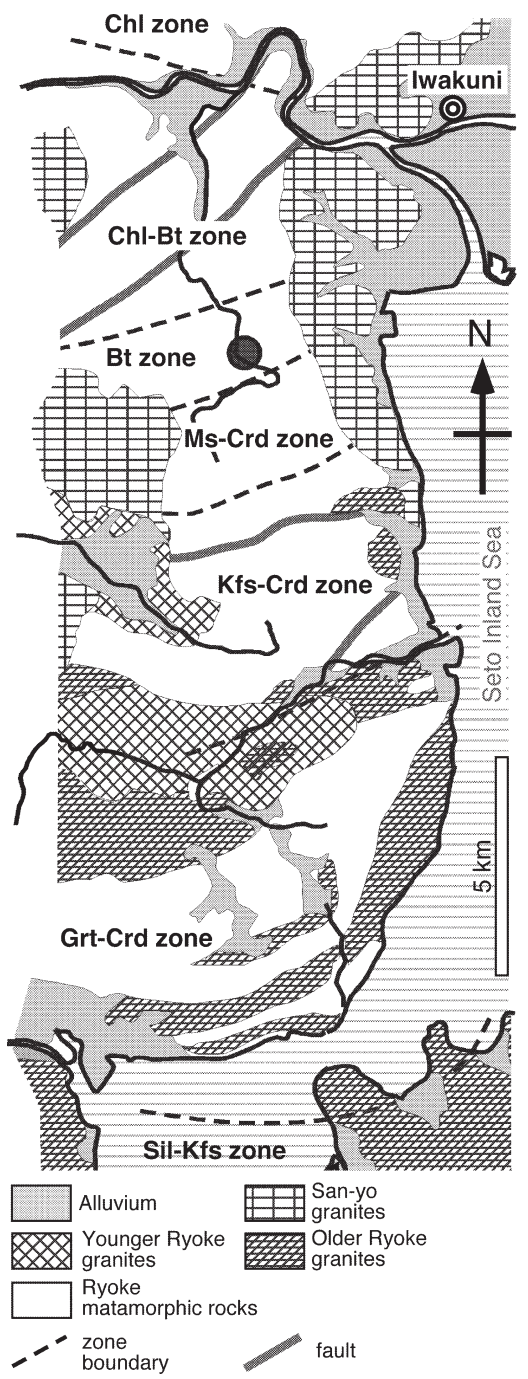

Figure 2. Metamorphic zonation map of the Yanai district, Yamaguchi Prefecture, SW Japan (partly modified from Ikeda, 2004). The closed circles represent the location of the Takabatake outcrop (see text). Abbreviations: Chl, chlorite; Bt, biotite; Ms, muscovite; Crd, cordierite; Kfs, K-feldspar; Grt, garnet; Sil, sillimanite.

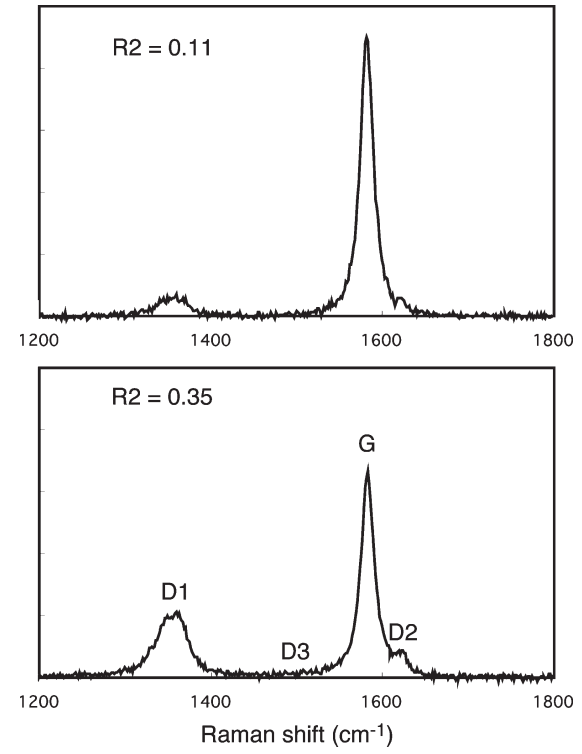

Figure 3. Raman spectra and $\mathrm{R} 2$ ratios of the $\mathrm{CM}$ with the highest $(\mathrm{R} 2=0.11$, top $)$ and the lowest $(\mathrm{R} 2=0.35$, bottom $)$ degrees of organization in the pelitic rocks of the biotite zone.

thermometric analysis of the inclusions has shown that the $\mathrm{CH}_{4} /\left(\mathrm{CO}_{2}+\mathrm{CH}_{4}\right)$ ratio of the fluid was as low as 0.10.2 . The salinity estimated from the Raman spectra of the stretching bands of the water in the inclusions was very low, ranging from 0 to $4 \mathrm{NaCl}$ eq.wt\% (Dubessy et al., 2002). Daughter minerals and minerals that have been accidentally trapped in the fluid inclusions have been characterized using Raman spectroscopy, e.g., CM, biotite, and native sulfur. It is interesting to note that the fluid inclusions containing $\mathrm{CM}$ frequently occur close to the solid CM inclusions.

\section{CARBONACEOUS MATTER}

The $\mathrm{CM}$ in the quartz veins and in the host pelitic rocks was analyzed using a Renishaw inVia Raman Microscope equipped with a $514 \mathrm{~nm}$ Ar laser. The first-order region of the Raman spectrum of the CM is composed of the following four bands: a $\mathrm{G}$ band occurring at $1580 \mathrm{~cm}^{-1}$, a D1 band occurring at $1350 \mathrm{~cm}^{-1}$, a D2 band occurring at 1620 $\mathrm{cm}^{-1}$, and a D3 band occurring at $1500 \mathrm{~cm}^{-1}$. The degree of organization of the $\mathrm{CM}$ was identified from the R2 ratio defined by the ratio of the $\mathrm{D} 1 /(\mathrm{G}+\mathrm{D} 1+\mathrm{D} 2)$ peak areas of the Raman spectrum (Beyssac et al., 2002). A smaller ratio represents a higher degree of organization. The D3 band almost disappeared, even for the CM with the largest ratios in the pelitic rocks in the biotite zone (Fig. 3).

Three types of $\mathrm{CM}$ were observed in the quartz veins: Type 1 solid $\mathrm{CM}$ without any fluid, Type $2 \mathrm{CM}$ 

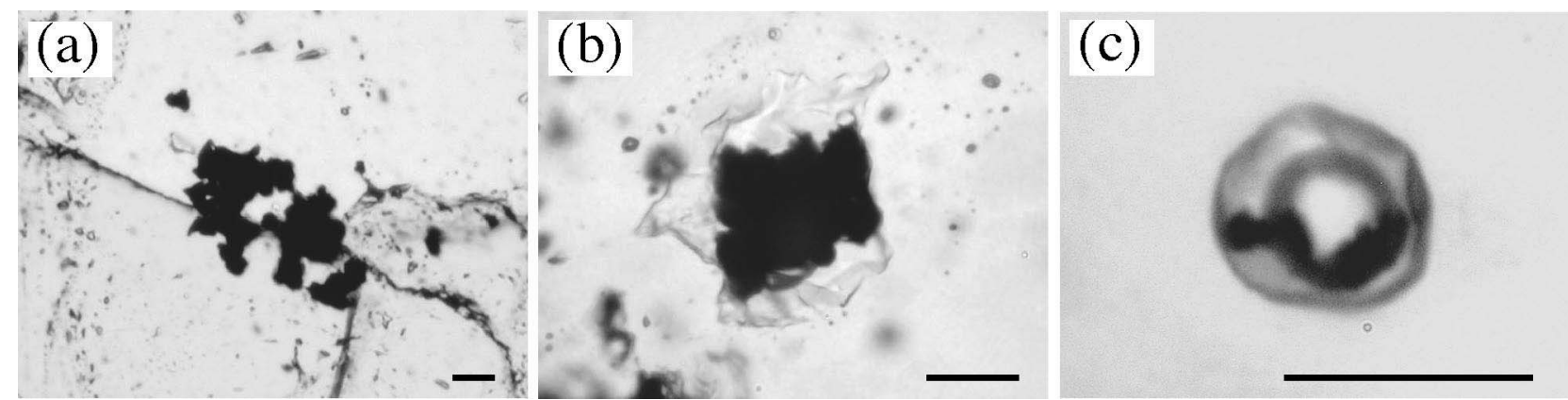

Figure 4. Photomicrographs of (a) Type 1, (b) Type 2, and (c) Type 3 CM inclusions in the quartz veins (see text for details). The scale bar denotes a length of $20 \mu \mathrm{m}$.

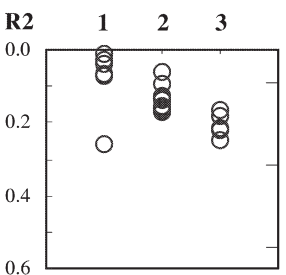

(a)

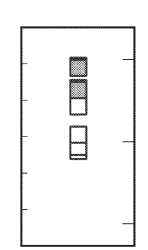

(b)

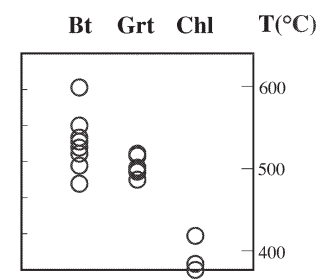

(c)
Figure 5. (a) R2 ratios (left-hand scale) and corresponding temperature (right-hand scale) of the Types 1,2, and $3 \mathrm{CM}$ inclusions in the quartz veins. (b) The $\mathrm{R} 2$ ratio in the host pelitic rocks of the biotite zone in the Yanai district. The hatched squares represent the ratio of the fine-grained CM, while the open squares show the ratio of the coarse-grained CM. (c) The $\mathrm{R} 2$ ratio in the Sanbagawa metamorphic rocks of the Asemi River section (see Beyssac et al., 2002 for the metamorphic zonation of the section). Abbreviations: Bt, biotite zone; Grt, garnet zone; Chl, chlorite zone.

having a large proportion of the volume, and Type $3 \mathrm{CM}$ with a small grain size in the fluid inclusions (Fig. 4). Considering that it occupied a large proportion of the inclusion volume, the Type $2 \mathrm{CM}$ was probably accidentally trapped from $\mathrm{CM}$ precipitated from the vein-forming fluids. The CM inclusions of Types 1, 2, and $3 \mathrm{CM}$ showed $\mathrm{R} 2$ ratios of: 0.01-0.26, 0.06-0.17, and 0.17-0.25, respectively (Fig. 5a).

On the other hand, two types of CM were observed at the grain boundaries in the host pelitic rocks of the biotite zone: fine-grained (average size $=5 \mu \mathrm{m}$ ) and scattered CM and coarse-grained (up to $120 \mu \mathrm{m}$ in size) and sparsely distributed CM (Fig. 6). These showed R2 ratios of 0.11-0.20 and 0.22-0.34 for the former and latter CMs, respectively (Fig. 5b). It was characteristic that the finegrained matrix CM showed homogeneous degrees of organization within a single particle, while various degrees of organization were observed within a single coarsegrained matrix CM. Although the types have not been specified, various R2 ratios were also obtained from the other metamorphic zones in the Yanai district.

Beyssac et al. (2002) proposed a new geothermome- ter based on the $\mathrm{R} 2$ ratio $\left(<641{ }^{\circ} \mathrm{C}\right.$, where $\left.\mathrm{R} 2=0\right)$. However, they pointed out afterwards that the $\mathrm{R} 2$ ratio for their geothermometer should be measured perpendicular to the c-axis of $\mathrm{CM}$ covered by a transparent mineral (Beyssac et al., 2003). Because the method of Beyssac et al. cannot be applied to the CM in the inclusions, we examined the effect of the orientation and coverage on the $\mathrm{R} 2$ ratio for the samples collected from the Asemi River section of the Sanbagawa metamorphic belt of the Ehime Prefecture, SW Japan, to which Beyssac et al. had referred their geothermometer. The results show that the R2 ratios measured on randomly orientating surfaces with or without coverage also followed the geothermometric results of Beyssac et al. (Fig. 5c). Hence, we could estimate the organization temperature of randomly orientated $\mathrm{CM}$ inclusions in the quartz veins and the host pelitic rocks in the Yanai district based on Beyssac et al.'s geothermometer (Fig. 5).

\section{CONCLUDING REMARKS}

Three types of CM inclusions with different degrees of organization have been recognized in the quartz veins in the pelitic rocks (biotite zone) of the Ryoke metamorphic belt in the Yanai district. Because the organization of the $\mathrm{CM}$ has been conceived as being an irreversible process, Type $3 \mathrm{CM}$ with the largest $\mathrm{R} 2$ ratio (i.e., the lowest degree of organization) may have been precipitated later than the other two types of CM. According to the geothermometer of Beyssac et al., which is based on the R2 ratio (Beyssac et al., 2002), the organization temperature of the CM inclusions of Types 1, 2, and 3 are 636-525, 615-564, and $567-530{ }^{\circ} \mathrm{C}$, respectively. Hence, the $\mathrm{CM}$ inclusions precipitated from the vein-forming fluids with decreasing temperatures from $>600^{\circ} \mathrm{C}$ to around $530{ }^{\circ} \mathrm{C}$. It should be noted that these temperatures are higher than the metamorphic temperature of the biotite zone in the Yanai district estimated by Ikeda (2004) $\left(450-453^{\circ} \mathrm{C}\right)$. In addition, the occurrence of rutile in the veins may also in- 


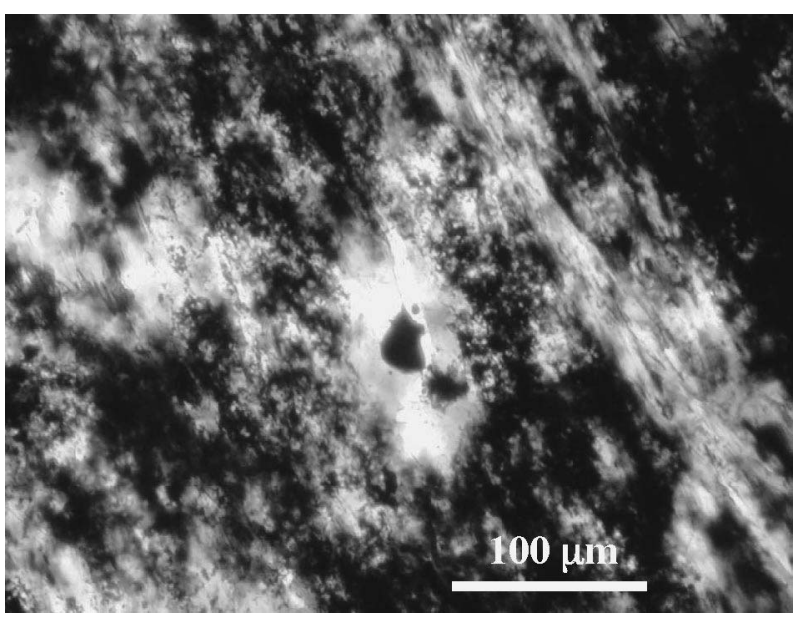

Figure 6. Photomicrograph of the coarse-grained CM (center) and the fine-grained $\mathrm{CM}$ (scattered) in the matrix of the pelitic rocks.

dicate that their formation temperature was above the rutile-anatase phase transition, although this transition temperature has not yet been confirmed under natural conditions. Therefore, we conclude that high temperature fluids had percolated through fractures that were now occupied by the quartz veins that had formed during the retrograde stage(s) of Ryoke metamorphism. These fluids may also have affected the degree of organization of the fine-grained CM particles in the host pelitic rocks and the coarse-grained CM particles that precipitated from them at a later stage.

\section{ACKNOWLEDGMENTS}

We would like to thank Dr. M. Watanabe, former professor of Hiroshima University, Japan, for his encouragement, Drs. K. Horie, M. Ogasawara, H. Murakami, and M. Fukuyama of the National Institute of Advanced Industrial Science and Technology, Japan, and Mr. Y. Shibata of Hiroshima University, Japan, for their technical support. We are indebted to Drs. T. Tsunogae, T. Itaya, and M. Enami for their careful reviews of this manuscript. Part of this work was supported by a fund from the Ministry of Education, Culture, Sports, Science and Technology of Japan (19540508).

\section{REFERENCES}

Beyssac, O., Goffe, B., Chopin, C. and Rouzaud, J.N. (2002) Raman spectra of carbonaceous material in metasediments: a new geothermometer. Journal of Metamorphic Geology, 20, 859-871.

Beyssac, O., Goffe, B., Petitet, J.N., Froigneux, E., Moreau, M. and Rouzaud, J.N. (2003) On the characterization of disordered and heterogeneous carbonaceous materials by Raman spectroscopy. Spectrochimica Acta Part A, 59, 2267-2276.

Dubessy, J., Lhomme, T., Boiron, M.C. and Rull, F. (2002) Determination of chlorinity in aqueous fluid using Raman spectroscopy of the stretching band of water at room temperature: application to fluid inclusions. Applied Spectroscopy, 56, 99-106.

Hoshino, K., Nagatomi, A., Watanabe, M., Okudaira, T. and Beppu, Y. (2006) Nahcolite in fluid inclusions from the Ryoke metamorphic rocks and its implication for fluid genesis. Journal of Mineralogical and Petrological Sciences, 101, 254-259.

Ikeda, T. (2004) Pressure-Temperature conditions of the Ryoke metamorphic rocks in Yanai district, SW Japan. Contributions to Mineralogy and Petrology, 146, 577-589.

Landis, C.A. (1971) Graphitization of dispersed carbonaceous material in metamorphic rocks. Contributions to Mineralogy and Petrology, 30, 34-45.

Okudaira, T., Hayasaka, Y., Hemeno, O., Watanabe, K., Sakurai, Y. and Ohtomo, Y. (2001) Cooling and inferred exhumation history of the Ryoke metamorphic belt in the Yanai district, south-west Japan: Constrains from $\mathrm{Rb}-\mathrm{Sr}$ and fission-track ages of gneissose granitoid and numerical modeling. The Island Arc, 10, 98-115.

Okuyama-Kusunose, Y. and Itaya, T. (1987) Metamorphism of carbonaceous material in the Tono contact aureole, Kitakami Mountains, Japan. Journal of Metamorphic Geology, 5, 121139.

Pasteris, D.J. and Wopenka, B. (1991) Raman spectra of graphite as indicators of degree of metamorphism. Canadian Mineralogist, 29, 1-9.

Rahl, M.J., Anderson, M.K., Brandon, T.M. and Fassoulas, C. (2005) Raman spectroscopic carbonaceous material thermometry of low-grade metamorphic rocks: calibration and application to tectonic exhumation in Crete Greece. Earth and Planetary Science Letters, 240, 339-354.

Wada, H., Tomita, T., Matsuura, K., Iuchi, K. and Ito, M. (1994) Graphitization of carbonaceous matter during metamorphism with references to carbonate and pelitic rocks of contact and regional metamorphisms, Japan. Contributions to Mineralogy and Petrology, 118, 217-228.

Wang, G.-F. (1989) Carbonaceous material in the Ryoke metamorphic rocks, Kinki district, Japan. Lithos, 22, 305-316.

Yamamoto, H., Terabayashi, M., Oasa, H., Kaneko, Y. and Anma, R. (2004) Competence contrast between pelitic schist and silicified pelitic schist in the Iwakuni-Yanai area of the Ryoke Belt, southwest Japan. Journal of Geological Society of Japan, 110, 119-122 (in Japanese with English abstract).

Manuscript received June 15, 2007

Manuscript accepted September 7, 2007

Manuscript handled by Masaki Enami 